\title{
Investigation of proteolytic, lipolytic activities and antibiotics susceptibility of some Pseudomonas bacteria isolated from raw milks
}

\author{
Çiğ suitlerden izole edilen bazı Pseudomonas bakterilerinin \\ proteolitik, lipolitik aktivitelerinin ve antibiyotik \\ duyarlılıklarının araștırılması
}

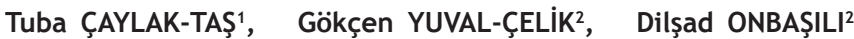

\section{ÖZET}

Amaç: Pseudomonas bakterileri proteaz ve lipaz gibi yüksek sıcaklıklarda kararlı ekstraselüler enzimleri sentezlerler. Bu nedenle Pseudomonas türleri çiğ veya pastörize sütte bozulmadan sorumlu en yaygın organizmalardır. Bu çalıșmanın amacı, çiğ sütlerden izole edilen 15 adet Pseudomonas sușunun antibiyotik duyarlılığı, proteolitik ve lipolitik aktivitelerini belirlemektir.

Yöntem: Buçalıșmada incelenen 15 adet Pseudomonas spp. sușu Türkiye'de Kayseri ve Niğde illerinden toplanan 50 adet çiğ süt örneğinden izole edilmiștir. Örnekler, laboratuvara transfer edilene kadar düșük sıcaklıkta muhafaza edilmiș ve 24 saat içerisinde analize alınmıștır. İzole edilen sușlar Analitik Profil İndeks (API 20 NE) kullanılarak tanımlanmıștır. Pseudomonas sușlarının proteolitik ve lipolitik aktiviteleri Skim Milk Agar (SMA) ve Tribütirin Agar (TA) besiyerlerinde test edilmiștir. Bir gecelik kültürlerden besiyerlerine nokta ekim yapılmıștır. İnkübasyondan sonra SMA ve TA besiyerlerinde olușan zonlar kumpas ile ölçülmüștür. Aynı zamanda, sușların yedi antibiyotiğe karșı duyarlılıkları test edilmiștir. Pseudomonas spp sușlarının antibiyotiklere karșı duyarlılığı ampisilin $(10 \mu \mathrm{g})$, amikasin $(30 \mu \mathrm{g})$, gentamisin $(10 \mu \mathrm{g})$, oflaksasin $(5 \mu \mathrm{g})$, tetrasiklin $(30 \mu \mathrm{g})$, kloramfenikol $(30 \mu \mathrm{g})$ ve sefuroksim $(30 \mu \mathrm{g})$ antibiyotikler için disk difüzyon yöntemi kullanılarak belirlenmiștir. Sonuçlar CLSI standartlarına göre yorumlanmıștır.

\section{ABSTRACT}

Objective: Pseudomonas bacteria secrete extracellular enzymes, extremely stable to high temperatures such as protease and lipase. Accordingly, Pseudomonas species are the most common organisms in raw or pasteurized milk at the time of spoilage. The aim of this study was to determine antibiotic sensitivity, proteolitic and lipolytic activity of fifteen Pseudomonas spp. strains isolated from raw milk samples.

Method: In the study, 15 Pseudomonas spp. strains were isolated from 50 raw milk samples collected from Kayseri and Nigde provinces in Turkey. The samples were maintained at low temperature during transfer to the laboratory and analyzed within $24 \mathrm{hrs}$. Isolated strains were identified by using Analytical Profile Indeks (API 20 NE). Proteolytic activities and lipolytic activities of Pseudomonas strains were tested in Skim Milk Agar (SMA) medium and in Tributyrin Agar (TA) medium. Overnight cultures were spot inoculated onto media. After incubation, the transparent zones of bacteria on the SMA and TA media were measured by calper rule. Also, the Pseudomonas spp. strains were tested for their susceptibility to seven antibiotics. Antibiotic susceptibility tests of Pseudomonas spp. strains to ampicillin $(10 \mu \mathrm{g})$, amikacin $(30 \mu \mathrm{g})$, gentamicin (10 $\mu \mathrm{g})$, oflaxacin $(5 \mu \mathrm{g})$, tetracyclin $(30 \mu \mathrm{g})$, chloramphenicol $(30 \mu \mathrm{g})$, cefuroxime $(30 \mu \mathrm{g})$ were determined by using the disc diffusion method. The results were described according to CLSI standards.

1' İstanbul Kriminal Polis Laboratuvarı Müdürlüğü, ISTANBUL

${ }^{2}$ Erciyes Üniversitesi, Eczacılık Fakültesi, Farmasötik Biyoteknoloji Anabilim Dalı, KAYSERI

İletişim/Corresponding Author: Gökçen YUVALI-ÇELIK

İstanbul Kriminal Polis Laboratuvarı Müdürlüğü, iSTANBUL $\quad$ Geliş Tarihi / Received : 11.02 .2013

Tel : +90352 $2076666 / 28400 \quad$ E-posta / E-mail : gycelik@erciyes.edu.tr Kabul Tarihi/ Accepted : 19.07 .2013

DOI ID : 10.5505/TurkHijyen.2013.42275

Çaylak-Taș T, Yuvalı-Çelik G, Onbașılı D. Investigation of proteolytic, lipolytic activities and antibiotics susceptibility of some Pseudomonas bacteria isolated from raw milks. Turk Hij Den Biyol Derg, 2013; 70(3): 147-52. 
Bulgular: Proteolitik aktiviteye sahip olduğu saptanan 14 Pseudomonas sușunun bu aktivitelerinin 14,2 ve 55,0 mm zon çapları arasında olduğu bulunmuștur. Lipolitik aktivite gösteren 13 sușun aktivitelerinin 5,3 ve $29,3 \mathrm{~mm}$ zon çapları arasında olduğu bulunmuștur. Test edilen Pseudomonas sușlarının \%57'sinin antibiyotiklere karșı duyarlı, \%35'inin dirençli ve \%8'sinin orta duyarlı olduğu belirlenmiștir.

Sonuç: Çalıșmamız ilaç sanayi ve diğer sektörlerde kullanılan mikrobiyal enzimlerin saflaștırılması ve ekonomik faydalarına yönelik konulara 1 șık tutacaktır.

Anahtar Sözcükler: Pseudomonas spp., tanımlama, antibiyotik duyarlılığı, proteolitik aktivite, lipolitik aktivite

\section{INTRODUCTION}

Refrigerated storage of milk is a common practice to control spoilage caused by the growth of mesophilic bacteria. However, psychrotrophic bacteria can grow readily at refrigeration temperatures. Psychrotrophic bacteria are ubiquitous in nature, with soil, water, plants and animals as their natural habitats (1). During storage under low temperature the raw milk undergoes spoilage due to the activity of proteinases and lipases released by psychrotrophic bacteria $(2,3)$.

Pseudomonas species are known as the most common spoilage organisms found in raw or pasteurized milk (2). Pseudomonas bacteria secrete extracellular enzymes such as protease and lipase which are extremely stable at high temperatures. Proteolytic and lipolytic activities of the psychrotrophs especially activities of Pseudomonas species, are valuable tools for the detection of spoilage of refrigerated foods and in assessing the shelf life of the foods (4). Proteolytic enzymes induce degradation of casein which is evident from the greyish colour and bitter taste of the milk. Lipases are responsible for degradation of milk fat associated with the development of a rancid and soapy flavour and occasionally a somewhat bitter taste due to release of low-molecular fatty acids (5).

Microorganisms move easily between ecosystems: from humans and animals to soil and water and/
Results: Fourteen Pseudomonas strains were determined that had proteolytic activities. Proteolytic activities of these strains were found between 14.2 and $55.0 \mathrm{~mm}$ zone diameters. Thirteen strains showed lipolytic activities. Lipolytic activities of these strains were found between 5.3 and $29.3 \mathrm{~mm}$ zone diameters. It was determined that $57 \%$ of Pseudomonas strains were susceptibility, $35 \%$ were resistant and $8 \%$ were intermediate susceptibility against antibiotics.

Conclusion: Our study shed light on purification and economic benefits of microbial enzymes used in the pharmaceutical industry and other sectors.

Key Words: Pseudomonas spp., identification, antibiotic susceptibility, proteolytic activity, lipolytic activity

or vice versa. It has been reported that antibiotic resistance genes acquired by organisms in one ecosystem can easily be transfered among organisms in various ecosystem by this way. In addition, there is a greater global mobility of living organisms facilitating the spread of microorganisms and their genes around the world (6). Foodborne bacteria including known pathogens and commensal bacteria display an extensive and diverse range of resistance to antimicrobial agents of human and veterinary importance (7). Any further spread of resistance among bacteria in food is likely to have an influence on public health (8).

In view of this, 15 Pseudomonas strains were isolated from raw milk samples and identified using of analytical profile index (API $20 \mathrm{NE}$ ) in the present study. The antibiotic sensitivity, proteolytic and lipolytic activities of these strains were also investigated.

\section{MATERIALS AND METHODS}

Sample collections: Raw milk samples were collected from various villages in the provinces of Kayseri and Nigde in Turkey between 01/03/2008 and $05 / 25 / 2009$. The samples were maintained at low temperature during transfer to the laboratory and analyzed within $24 \mathrm{~h}$. 
Isolation and Identification of Bacteria: Fifty raw milk samples were homogenized by vigorous shaking and diluted in sterile physiological water. Homogenized samples were diluted serially from $10^{-1}$ to $10^{-7}$ and then $0.1 \mathrm{~mL}$ of the samples and/or dilutions were inoculated on McConkey agar (Merck 1.05465) plates. Afterwards inoculated plates were incubated at $37^{\circ} \mathrm{C}$ for $24 \mathrm{~h}$. At the end of incubation period lactose (-) colonies on McConkey Agar were picked up and inoculated onto the Pseudomonas CFC agar media (Merck 1.07620). Inoculated media were incubated at $37{ }^{\circ} \mathrm{C}$ for $24-48 \mathrm{~h}$. After incubation Gram staining and examination under a microscope were performed on randomly selected colonies (9). The isolated bacteria were evaluated firstly according to their colony morphology, the Gram-stain, catalase activity, ability to grow at $+40^{\circ} \mathrm{C}$ and $+42^{\circ} \mathrm{C}$. Further identification of Pseudomonas sp. at species level was performed by using analytical profile index (API $20 \mathrm{NE}$ ). Identified strains were preserved in $15 \%(\mathrm{v} / \mathrm{v})$ glycerol at $-20^{\circ} \mathrm{C}$ until use.

Antibiotic Susceptibility: In the antibiotic susceptibility study; Mueller-Hinton Agar (MHA) (LAB039) medium and as antibiotics: ampicillin
$(10 \mu \mathrm{g})$, amikacin $(30 \mu \mathrm{g})$, gentamicin $(10 \mu \mathrm{g})$, oflaxacin $(5 \mu \mathrm{g})$, tetracycline $(30 \mu \mathrm{g})$, chloramphenicol (30 $\mu \mathrm{g})$, cefuroxime $(30 \mu \mathrm{g})$ (Bioanalyse) were used. The antibiotic susceptibility tests of Pseudomonas spp. strains were determined by using disc diffusion method. The results were described according to CLSI standards.

Proteolytic and lipolytic activity of Pseudomonas strains: Proteolytic and lipoliytic activities of Pseudomonas strains were tested in Skim Milk Agar (SMA) (Merck 1.15338) and Tributyrin Agar (TA) (Merck 1.01957) media, respectively. Overnight grown cultures were spot inoculated onto the media. After incubation at $37^{\circ} \mathrm{C}$ for $24 \mathrm{~h}$, the transparent zones of bacteria on the SMA and TA media were measured by calper rule (10).

\section{RESULTS}

In this study, total of 15 strains were isolated from raw milk and identified by using API $20 \mathrm{NE}$ (Table 1). These isolates were identified in the species Pseudomonas fluorescens ssp. indologenes, Pseudomonas vesicularis, Pseudomonas luteola and Pseudomonas aeruginosa.

Table 1. Pseudomonas species isolated from raw milk and their geographical origin

\begin{tabular}{cccc}
\hline Number & Strain & Species & Origin \\
\hline 1 & $\mathrm{~T}_{1}$ & P. luteola & Kayseri Province \\
2 & $\mathrm{~T}_{2}$ & P. vesicularis & Niğde Province \\
3 & $\mathrm{~T}_{3}$ & P. vesicularis & Niğde Province \\
4 & $\mathrm{~T}_{4}$ & P. vesicularis & Kayseri Province \\
5 & $\mathrm{~T}_{5}$ & P. aeruginosa & Niğde Province \\
6 & $\mathrm{~T}_{6}$ & P. fluorescens ssp. indolegenes & Niğde Province \\
7 & $\mathrm{~T}_{7}$ & $P$. fluorescens ssp. indolegenes & Niğde Province \\
8 & $\mathrm{~T}_{8}$ & P. fluorescens ssp. indolegenes & Niğde Province \\
9 & $\mathrm{~T}_{9}$ & $P$. fluorescens ssp. indolegenes & Niğde Province \\
10 & $\mathrm{~T}_{10}$ & P. fluorescens ssp. indolegenes & Niğde Province \\
11 & $\mathrm{~T}_{11}$ & P. fluorescens ssp. indolegenes & Niğde Province \\
12 & $\mathrm{~T}_{12}$ & P. fluorescens ssp. indolegenes & Niğde Province \\
13 & $\mathrm{~T}_{13}$ & P. fluorescens ssp. indolegenes & Niğde Province \\
14 & $\mathrm{~T}_{14}$ & P. fluorescens ssp. indolegenes & Niğde Province \\
15 & $\mathrm{~T}_{15}$ & $P$. fluorescens ssp. indolegenes & Niğde Province \\
\hline
\end{tabular}


The Pseudomonas strains were tested for their susceptibility to ampicillin, amikacin, gentamicin, oflaxacine tetracyclin, chloramphenicol and cefuroxime. The results of the disc diffusion assays are shown in Table 3. It was found that $57 \%$ of Pseudomonas strains were susceptible, 35\% were resistant and $8 \%$ of them showed intermediate susceptibility against seven antibiotics (Table 2 ). This study revealed that while investigated Pseudomonas strains showed high susceptibility against amikacin, oflaxacin, gentamicin antibiotics, they were resistant against ampicillin and cefuroxime.

Table 2. Antibiotic resistance of Pseudomonas strains

\begin{tabular}{|c|c|c|c|c|c|c|c|}
\hline \multirow{2}{*}{$\begin{array}{l}\text { Pseudomonas } \\
\text { strains }\end{array}$} & \multicolumn{7}{|c|}{ Antibiotics } \\
\hline & $\mathrm{AM}$ & TE & $\mathrm{AK}$ & OFX & $\mathrm{CN}$ & C & CXM \\
\hline $\begin{array}{l}\text { P. luteola } \\
\mathrm{T}_{1}\end{array}$ & $\mathrm{R}$ & I & $S$ & $S$ & $S$ & $S$ & $\mathrm{R}$ \\
\hline $\begin{array}{l}P \text {. vesicularis } \\
\mathrm{T}_{2}\end{array}$ & $\mathrm{R}$ & $S$ & $S$ & $S$ & $S$ & $S$ & $\mathrm{R}$ \\
\hline $\begin{array}{l}P . \text { vesicularis } \\
\mathrm{T}_{3}\end{array}$ & $\mathrm{R}$ & $S$ & $S$ & $S$ & $\mathrm{R}$ & $S$ & $\mathrm{R}$ \\
\hline $\begin{array}{l}\text { P. vesicularis } \\
\mathrm{T}_{4}\end{array}$ & $\mathrm{R}$ & $S$ & $S$ & $S$ & $\mathrm{R}$ & $S$ & $\mathrm{R}$ \\
\hline $\begin{array}{l}\text { P. aeruginosa } \\
\mathrm{T}_{5}\end{array}$ & $\mathrm{R}$ & $\mathrm{R}$ & $S$ & $S$ & $S$ & 1 & $\mathrm{R}$ \\
\hline $\begin{array}{l}\text { P. fluorescens ssp. } \\
\text { indolegenes } \mathrm{T}_{6}\end{array}$ & $\mathrm{R}$ & $\mathrm{R}$ & $S$ & $\mathrm{~S}$ & $S$ & $\mathrm{R}$ & $\mathrm{R}$ \\
\hline $\begin{array}{l}\text { P. fluorescens ssp. } \\
\text { indolegenes } T_{7}\end{array}$ & $\mathrm{R}$ & $\mathrm{R}$ & $S$ & $S$ & $S$ & $\mathrm{R}$ & $\mathrm{R}$ \\
\hline $\begin{array}{l}\text { P. fluorescens ssp. } \\
\text { indolegenes } \mathrm{T}_{8}\end{array}$ & $\mathrm{R}$ & $\mathrm{R}$ & $S$ & $\mathrm{~S}$ & $S$ & 1 & $\mathrm{R}$ \\
\hline $\begin{array}{l}\text { P. fluorescens ssp. } \\
\text { indolegenes } T_{9}\end{array}$ & $\mathrm{R}$ & I & $S$ & $\mathrm{~S}$ & $S$ & 1 & $\mathrm{R}$ \\
\hline $\begin{array}{l}\text { P. fluorescens ssp. } \\
\text { indolegenes } \mathrm{T}_{10}\end{array}$ & $\mathrm{R}$ & I & $S$ & $S$ & $S$ & 1 & $\mathrm{R}$ \\
\hline $\begin{array}{l}\text { P. fluorescens ssp. } \\
\text { indolegenes } T_{11}\end{array}$ & $\mathrm{R}$ & $S$ & $\mathrm{~S}$ & $\mathrm{~S}$ & $S$ & $\mathrm{~S}$ & $\mathrm{R}$ \\
\hline $\begin{array}{l}\text { P. fluorescens ssp. } \\
\text { indolegenes } T_{12}\end{array}$ & I & $S$ & $S$ & $\mathrm{~S}$ & $S$ & $\mathrm{R}$ & $\mathrm{R}$ \\
\hline $\begin{array}{l}\text { P. fluorescens ssp. } \\
\text { indolegenes } \mathrm{T}_{13}\end{array}$ & $\mathrm{R}$ & $S$ & $S$ & $\mathrm{~S}$ & $S$ & $\mathrm{~S}$ & $\mathrm{R}$ \\
\hline $\begin{array}{l}\text { P. fluorescens ssp. } \\
\text { indolegenes } \mathrm{T}_{14}\end{array}$ & $\mathrm{R}$ & $S$ & $S$ & $S$ & $S$ & $\mathrm{R}$ & $\mathrm{R}$ \\
\hline
\end{tabular}

AM: Ampicillin TE: Tetracycline AK: Amikacin OFX: Ofloxacin CN: Gentamicin C: Chloramphenicol CXM: Cefuroksime R: resistant, S: susceptibility, I: intermediate-susceptibility
Proteolytic activities of Pseudomonas isolates were stated in Table 3. It was determined that 14 strains had proteolytic activities. Proteolytic activities of these strains were found between 14.2$55.0 \mathrm{~mm}$ with an average $28.1 \mathrm{~mm}$ zone diameter. The highest proteolytic activity of $55.0 \mathrm{~mm}$ was found in P. fluorescens ssp. indologenes T7 strain. The lowest proteolytic activity $(14.2 \mathrm{~mm})$ was determined in P. fluorescens ssp. indologenes T11 strain. (Table 3).

Table 3. Zone diameters ( $\mathrm{mm}$ ) obtained for proteolytic and lipolytic activities of Pseudomonas strains

\begin{tabular}{|c|c|c|}
\hline \multirow[b]{2}{*}{$\begin{array}{l}\text { Pseudomonas } \\
\text { strains }\end{array}$} & \multicolumn{2}{|c|}{ *** Zone diameters $(\mathrm{mm})$} \\
\hline & $\begin{array}{l}\text { Proteolytic } \\
\text { activity }\end{array}$ & Lipolytic activity \\
\hline P. luteola $\mathrm{T}_{1}$ & - & - \\
\hline P. vesicularis $T_{2}$ & $36.3 \pm 2.9$ & $5.3 \pm 0.2$ \\
\hline P. vesicularis $T_{3}$ & $25.7 \pm 4.8$ & $9.1 \pm 0.4$ \\
\hline P. vesicularis $\mathrm{T}_{4}$ & $34.8 \pm 8.9$ & $11.1 \pm 0.8$ \\
\hline P. aeruginosa $\quad T_{5}$ & $21.0 \pm 0.0$ & $7.5 \pm 0.1$ \\
\hline $\begin{array}{l}\text { P. fluorescens ssp. } \\
\text { indolegenes } \mathrm{T}_{6}\end{array}$ & $16.0 \pm 0.0$ & $12.2 \pm 1.5$ \\
\hline $\begin{array}{l}\text { P. fluorescens ssp. } \\
\text { indolegenes } T_{7}\end{array}$ & $55.0 \pm 14.1^{*}$ & $21.8 \pm 4.9$ \\
\hline $\begin{array}{l}\text { P. fluorescens ssp. } \\
\text { indolegenes } T_{8}\end{array}$ & $41.4 \pm 16.2$ & $29.3 \pm 3.0^{*}$ \\
\hline $\begin{array}{l}\text { P. fluorescens ssp. } \\
\text { indolegenes } T_{9}\end{array}$ & $53.9 \pm 7.8$ & $14.9 \pm 2.4$ \\
\hline $\begin{array}{l}\text { P. fluorescens ssp. } \\
\text { indolegenes } \mathrm{T}_{10}\end{array}$ & $46.1 \pm 10.0$ & $25.2 \pm 0.6$ \\
\hline $\begin{array}{l}\text { P. fluorescens ssp. } \\
\text { indolegenes } \mathrm{T}_{11}\end{array}$ & $14.2 \pm 5.7$ & $19.8 \pm 0.7$ \\
\hline $\begin{array}{l}\text { P. fluorescens ssp. } \\
\text { indolegenes } \mathrm{T}_{12}\end{array}$ & $23.5 \pm 2.4$ & $21.2 \pm 5.4$ \\
\hline $\begin{array}{l}\text { P. fluorescens ssp. } \\
\text { indolegenes } T_{13}\end{array}$ & $29.2 \pm 3.1$ & $13.0 \pm 3.9$ \\
\hline $\begin{array}{l}\text { P. fluorescens ssp. } \\
\text { indolegenes } \mathrm{T}_{14}\end{array}$ & $15.4 \pm 0.6$ & - \\
\hline $\begin{array}{l}\text { P. fluorescens ssp. } \\
\text { indolegenes } T_{15}\end{array}$ & $26.3 \pm 0.9$ & $9.4 \pm 0.6$ \\
\hline Average & $28.1 \pm 5.16^{* *}$ & $15.4 \pm 1.6^{* *}$ \\
\hline
\end{tabular}

-: Not determined.

* The highest proteolytic and lipolytic activities zone diameter

** The average proteolytic and lipolytic activities zone diameter

*** Values are the means \pm standard deviations of triplicate measurements. 
Lipolytic activity of Pseudomonas spp. strains are also stated in Table 3. Lipolytic activities were tested in Tributyrin Agar (TA) medium. It was found that 13 strains had lipolytic activities. Lipolytic activities of these strains were found between 5.3-29.3 with an average $15.4 \mathrm{~mm}$ zone diameter. The highest zone diameter of lipolytic activity $29.3 \mathrm{~mm}$ was found in $P$. fluorescens ssp. indologenes T8 strain. The lowest lipolytic activity $(5.3 \mathrm{~mm})$ was detected in P. vesicularis $\mathrm{T} 2$ strain (Table 3 ).

\section{DISCUSSION}

Pseudomonas species have been reported as important decomposers of organic matter in soil, water and food products, but are also pathogens in plants, animals and humans (11). Water and soil are known as the primary sources of Pseudomonas sp. $(12,13)$. Hose nozzles and milking equipment can become colonized by Pseudomonas. Also, API 20 NE provided good identification of dairy Pseudomonas isolates to the species level $(14,15)$. In the present study, 15 Pseudomonas strains isolated from raw milk, identified by using API 20 NE and good identification was obtained.

Antibiotic resistance is an accepted concern for the management of disease in humans, animals and plants. The intense research efforts to elucidate mechanisms of resistance have focused on genes derived from a narrow range of environments (6). The Pseudomonas genus corresponds to a diverse and ecologically significant group of bacteria that are found in natural environments. Such a universal distribution can be associated with the capacity of Pseudomonas species to adapt to various environmental conditions and degrade a wide range of substrates (16). Most of the known resistance determinants have been discovered in clinical and veterinary bacterial isolates, whereas other environmental reservoirs of antibiotic resistance are not well characterized (6). It is not known whether antibiotic resistance genes move readily from environmental reservoirs to clinical settings, but future work should consider the potential contributions of soil bacteria to the problem of antibiotic resistance. Multiple drug resistant (MDR) bacteria in processed foods are potent biological hazards as there are possibilities for resistance genes to be spread to human beings via food (17). Antibiogram of the all the investigated isolates revealed that, of the seven antibiotics tested, almost all of the isolates was resistant to ampicillin and cefuroxime. Results are not suggestive of the trait of MDR in the isolate.

Pseudomonas spp. are the most important group of Psychrotrophes associated with spoilage, they grow rapidly at refrigeration temperatures and often dominate the microbial population Also, some Pseudomonas spp. have been reported to survive during heat treatment used in pasteurization of milk (18). It can be seen in previous studies that Pseudomonas, particularly $P$. fluorescens, was frequently isolated from refrigerated raw milk and associated with proteolysis and lipolysis $(2,19,20)$. Extra cellular proteinases and lipases from psychrotrophic Pseudomonas are recognized as the primary microbial spoilage enzymes of dairy products $(21,22)$.

Craven and Macauley reported that $5 \%$ total of 26 Pseudomonas strains showed proteolytic activities (15 $\mathrm{mm}$, zone diameter) in SMA (23). Same researchers revealed that $10 \%$ of $P$. fluorescens strains isolated from milk had proteolytic activity with $15-17 \mathrm{~mm}$ zone diameters (24).

In a previously performed study (25) the microflora of 19 samples of refrigerated bulk tank milk were examined and they found that the number of Pseudomonas spp. were increased significantly in milk stored at $2^{\circ}, 4^{\circ}$ and $7^{\circ} \mathrm{C}$ whilst other psychrotrophic flora decreased. Al-Ashmawy et al., found that lipolytic properties of the isolated Pseudomonas spp from table butter proved that all tested five $P$. fragi and three $P$. fluorescens strains produced lipolytic activity (26).

In this study we determined antibiotics susceptibility of Pseudomonas strains. Also we only assessed ability to produce protease and lipase enzymes on SMA and TA media to predict spoilage potential of strains. The use of microbial enzymes in food, pharmaceutical, textile, paper, leather, and other industries are numerous and are increasing rapidly. Therefore, determination and purification of microbial enzymes are very important for industrial applications. 


\section{REFERENCES}

1. Cousin MA. Presence and activity of psychrotrophic microorganisms in milk and dairy products: a review. J Food Prot, 1982; 45: 172-207.

2. Sorhauge T, Stepaniak L. Psychrotrophs and their enzymes in milk and dairy products: quality aspects. Trends Food Sci Technol, 1997; 8: 35-41.

3. Braun P, Fehlhaber K. Combined effect of temperature, aw and $\mathrm{pH}$ on enzymatic activity of spoilage causing bacteria. Milchwissenschaft, 2002; 57: 134-6.

4. Ma YD, Barbano M, Santos $\mathrm{M}$. Effect of $\mathrm{CO}_{2}$ addition to raw milk on proteolysis and lipolysis at $4^{\circ} \mathrm{C}$. J Dairy Sci, 2003; 86: 1616-31.

5. Vyletělová M, Hanuš O. Effect of contamination by Pseudomonas fluorescens on principal components and technological parameters of pasteurized milk during storage. Czech J Food Sci, 2000; 18: 224-34.

6. Nwosu VC. Antibiotic resistance with particular reference to soil microorganisms. Res Microbiol, 2001; 152: 421-30.

7. Alatossava PM, Alatossava T. Antibiotic resistance of raw-milk associated psychrotrophic bacteria. Microbiol Res, 2007; 162: 115-23.

8. Beena AK, Ranjini AR, Riya TG. Isolation of psychrotrophic multiple drug resistant Pseudomonas from pasteurised milk. Veterinary World, 2011; 4(8): 349-52.

9. Uraz G, Citak S. An investigation about the distribution and isolation of Pseudomonas from raw milk samples obtained from different areas. Turk J Agric For, 1998; 22: 469-74.

10. Rajmohan S, Dodd CER, Waites WM. Enzymes from isolates of Pseudomonas fluorescens involved in food spoilage. J Appl Microbiol, 2002; 93: 205-13.

11. Palleroni NJ. Pseudomonas classification. Anton. Leeuw, 1993; 64: 231-51.

12. Erskine RJ, Unflat JG, Eberhart RJ, Hutchinson LJ, Hicks CR, Spencer SB. Pseudomonas mastitis: Difficulties in detection and elimination from contaminated wash-water systems. J Am Vet Med Assoc, 1987; 191 (7): 811-5.

13. Jay JM. Taxonomy, Role, and Significance of Microorganisms in Food. In: Modern Food Microbiology. Gaithersburg MD, Aspen Publishers, 2000; p. 13.

14. Vachée A, Mossel DAA, Leclerc A. Antimicrobial activity among Pseudomonas and related strains of mineral water origin. J Appl Microbiol, 1997; 83: 652-8.
15. Wiedmann M, Weilmeier D, Dineen SS, Ralyea R, Boor KJ. Molecular and phenotypic characterization of Pseudomonas isolated from milk. Appl Environ Microb, 2000; 66(5): 2085-95.

16. Palleroni NJ. Human and Animal Pathogenic Pseudomonas. The Prokaryotes- A Handbook on the Biology of Bacteria, Volume: 6, Springer-Verlag, New York, 1992; p. 1194.

17. Riesenfeld CS, Goodman RM, Handelsman J. Uncultured soil bacteria are a reservoir of new antibiotic resistance genes. Environ Microbiol, 2004; 6: 981-90.

18. Abad P, Villafafila A, Frias JD, Rodriguez-Fernandez C. Extracellular lipolytic activity from Pseudomonas fluorescence biovar1 (Pseudomonas fluorescencs $\mathrm{Ncl}$ ). Milchwissenschaft, 1993; 48 (12): 680-3.

19. Malik RK, Prasad R, Mathur DK. Effect of some nutritional and environmental factors on extracellular protease production by Pseudomonas sp. B-25. Lait, 1985; 65: 169-83.

20. Matselis E, Roussis IG. Proteinase and lipase production by Pseudomonas fluorescens. Proteolysis and lipolysis in thermized ewe's milk. Food Control, 1998; 9: 251-9.

21. Sorhauge T, Stepaniak L. Microbial Enzymes in the Spoilage of Milk and Dairy Products, In: Food Enzymology Vol. I (P.F., Fox, ed.), Elsevier Applied Sci., London, 1991; p. 169-218.

22. Vyletělová $M$, Hanuš $O$, Urabanova $E$, Kopuenecz P. Occurrence and identification of proteolytic and lipolytic and psychotropic bacteria in bulk cow milk. Veterinar. St Vi, 1999; 49(11): 480-2.

23. Craven H, Macauley BJ. Microorganisms in pasteurised milk after refrigerated storage 1. identification of types. Aust J Dairy Tech, 1992; 42: 38-45.

24. Craven H, Macauley BJ, Microorganisms in pasteurised milk after refrigerated storage 3 . effect of milk processor. Aust J Dairy Tech, 1992; 42: 50-5.

25. Stewart DB, Murray JG, Neill SD. Lipolytic activity of organisms isolated from refrigerated bulk milk. Annual Bulletin, Int. Dairy Fed, 1975; 86: 38-50.

26. Al-Ashmawy MA, Al-Shimaa El-Dyasety A. Lipolytic and proteolytic activities of Psedomonas spp. isolated from table butter. Mansoura Vet Med J, 2008; 10 (1): 73-8. 